\title{
Some Biological Activities of Cycloprate, to the Citrus Red Mite, Panonychus citri (McGregor)
}

\author{
Shoji Asano and Masaharu KameI \\ Laboratories of Agricultural Chemicals Research, Tokushima Factory, \\ Otsuka Pharmaceutical Co., Ltd., Kawauchi-cho, Tokushima 771-01, Japan
}

(Received June 17, 1977)

\begin{abstract}
Some biological characteristics of a new chemical class of selective miticides, cycloprate (ZARDEX ${ }^{\circledR}$, ZR-0856, hexadecyl cyclopropanecarboxylate) against the citrus red mite, Panonychus citri (McGregor), were investigated. High ovicidal activity of the compound was observed against eggs of all stages; most embryos died at the pharate larval stage. Delayed ovicidal effects resulted in larval death soon after hatching. Insecticidal activity was most pronounced in the larval stage and decreased in further developmental stages. The death of nymphs occurred mostly during molting. A sterilizing activity against female adults was shown from both egg hatch and the survival of hatched larvae, but this was only a transient effect. These facts suggest that the mode of action of cycloprate might be quite different from that of other miticides in current use.
\end{abstract}

\section{INTRODUCTION}

The development of resistance to organic agricultural pesticides in several important pests has always been a serious problem in practical pest control. The resistance in mites usually develops faster than in other pests. This is probably due to their many reproductive cycles during one season and the required frequent application of miticides. Several measures have been taken to prevent the development of resistance; for example, limiting successive applications with the same miticide and recommending the rotational use of different miticides., ${ }^{1,2)}$ However, control of mites which have already developed resistance to certain miticides cannot improve substantially by using other miticides of the same chemical type because these will usually show some cross-resistance. Therefore, one of the critical properties required for new miticides is a mode of action different from that of miticides in current use. Also, more emphasis has recently been placed on greater selectivity of miticide in reduced hazards to natural enemy and mammals as well as in longer lasting control of the target pest species. Cycloprate
(ZARDEX ${ }^{\circledR}$, ZR-0856, hexadecyl cyclopropanecarboxylate) represents a new chemical class of miticides which has been developed by Zoecon Corp., Palo Alto, California, U.S.A. ${ }^{3,4)}$ This compound shows a broad spectrum miticidal activity against many phytophagous mite species with little or no adverse effects on beneficial predatory mites and on beneficial insects. It also shows little toxicity to mammals and wildlife. The present studies were conducted to clarify some biological characteristics of cycloprate in the citrus red mite, Panonychus citri (McGregor) in laboratory tests.

\section{MATERIALS AND METHODS}

Test colonies of the citrus red mite, Panonychus citri (McGregor) were collected in citrus orchards at Tokushima Prefectural Fruit Experimental Station in the spring of 1975 and propagated on 3-4 year old citrus trees in our laboratory. Laboratory bioassays were conducted with citrus leaf discs $1.0 \mathrm{~cm}$ in diameter which were placed on filter paper on the lid of $80 \mathrm{ml}$ volume plastic cups containing tap water. The filter paper was kept moist through a cotton band making contact with 
the water in the cup. For ovicidal tests, four to five female adults per leaf disc were allowed to oviposit for 24 hours and then removed. The leaf discs with eggs were then dipped in test solutions. For evaluation of residual contact ovicidal activity, oviposition test was also conducted on previously dipped leaf discs. Controls were treated with tap water. Each dose level and control had nine replicate leaf discs. The number of unhatched eggs and the hatched dead and surviving larvae were recorded on the 10-12th day after treatment. Experiments for lethal activity on mobile stages were conducted by transferring larvae, protonymphs, deutonymphs or adults individually to leaf discs previously treated by dipping into the test solutions. Their survival was recorded daily for 5-10 days. In the sterilization tests, leaves of citrus seedlings infested with nonsynchronous mite populations were treated by dipping into test solutions. After this, sixty female adults from these were transferred to untreated leaf discs (two mites per disc) and allowed to oviposit for 24 hours. Surviving adults were again transferred to other untreated leaf discs and allowed to oviposit for another 24 hours. Egg hatch and larval survival were recorded on the 11 th day after each mite transferal. All laboratory assays were carried out at $25 \pm 1{ }^{\circ} \mathrm{C}$ and $70-$ $80 \%$ R.H.

The chemical structure of the test compound is shown below. Emulsifiable concentrates $(27.28 \%$ active ingredient) were used to make the test dilution. A spreader-sticker,
Kumiten, was added at $0.01 \%$ to each test dilution.

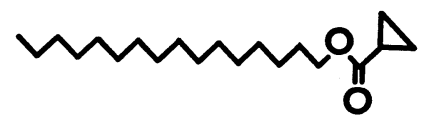

\section{RESULTS}

\section{Ovicidal Activity}

Table 1 shows the direct contact and the residual contact ovicidal activities of cycloprate indicated as the average percentage of egg hatch and larval survival 10-12 days after treatment for four replicated experiments. In the controls, $95.9-96.8 \%$ of the eggs hatched and all larvae survived. Cycloprate distinctly inhibited egg hatch and also affected survival of the hatched larvae; most died near the egg shells from which they emerged. It is likely that death of the hatched larvae is caused by a delayed ovicidal effect of cycloprate applied in the egg stage. The quantitative relation between the concentration and the inhibitory activity of cycloprate for egg hatch or larval survival was evaluated by probit analysis. The concentration-response regression lines and the $50 \%$ inhibitory concentrations with their 95\% confidence limits are summarized in Table 2. The slope of the regression lines ranged between 1.9553 and 2.7227. These values are small compared with the slopes of conventional miticides. The 50\% inhibitory concentrations of cycloprate in the direct and the residual contact ovicidal activity are 67.3 and $144.4 \mathrm{ppm}$ based upon the number

Table 1 Ovicidal activity of cycloprate by direct or residual contact exposure of the citrus red mite, Panonychus citri (McGregor).

\begin{tabular}{ccccccccc}
\hline \multirow{2}{*}{$\begin{array}{c}\text { Concn. } \\
(\mathrm{ppm})\end{array}$} & \multicolumn{3}{c}{ Direct contact } & & \multicolumn{3}{c}{ Residual contact } \\
\cline { 2 - 3 } \cline { 7 - 8 } & $\begin{array}{c}\text { No. of } \\
\text { eggs }\end{array}$ & $\begin{array}{c}\% \text { Egg } \\
\text { hatch }\end{array}$ & $\begin{array}{c}\text { \% Larval } \\
\text { survival }\end{array}$ & & $\begin{array}{c}\text { No. of } \\
\text { eggs }\end{array}$ & $\begin{array}{c}\% \text { Egg } \\
\text { hatch }\end{array}$ & $\begin{array}{c}\text { \% Larval } \\
\text { survival }\end{array}$ \\
\hline 500 & - & - & - & & 165 & 7.7 & 1.7 \\
250 & 170 & 1.6 & 0.5 & & 215 & 23.8 & 13.0 \\
125 & 248 & 28.1 & 17.5 & & 221 & 59.2 & 26.0 \\
62.5 & 209 & 62.9 & 36.0 & & 221 & 85.2 & 60.3 \\
31.3 & 188 & 74.4 & 56.3 & & 247 & 94.9 & 89.6 \\
15.6 & 223 & 87.4 & 77.9 & & 163 & 96.7 & 94.1 \\
7.81 & 270 & 93.7 & 91.9 & & - & - & - \\
3.91 & 190 & 91.3 & 90.3 & & - & - & - \\
Control & 259 & 95.9 & 95.9 & & 263 & 96.8 & 96.8 \\
\hline
\end{tabular}


Table 2 Concentration-inhibition regression lines and the 50\% inhibition concentration $\left(\mathrm{IC}_{50}\right)$ by probit analysis in the data shown in Table 1.

\begin{tabular}{clcc}
\hline Exposure & \multicolumn{1}{c}{ Inhibition } & Regression lines & $\begin{array}{c}\text { IC } \\
\text { confidence limits } 95 \%\end{array}$ (ppm) \\
\hline Direct & Egg hatch & $Y=5+1.9553(X-1.8282)$ & $67.3(60.9-74.9)$ \\
contact & Larval survival & $Y=5+2.0347(X-1.6088)$ & $40.6(37.0-44.7)$ \\
Residual & Egg hatch & $Y=5+2.5784(X-2.1595)$ & $144.4(133.4-156.9)$ \\
contact & Larval survival & $Y=5+2.7227(X-1.9314)$ & $85.4(79.2-92.0)$ \\
\hline
\end{tabular}

Table 3 Direct contact ovicidal activity of cycloprate against eggs of different age of the citrus red mite Panonychus citri (McGregor).

\begin{tabular}{cccc}
\hline $\begin{array}{c}\text { Age of egg } \\
\text { (hrs postoviposition) }\end{array}$ & $\begin{array}{c}\text { No. of } \\
\text { eggs }\end{array}$ & $\begin{array}{c}\text { IC50 with 95\% confidence limits (ppm) } \\
\text { Egg hatch }\end{array}$ & Larval survival \\
\hline $0-24$ & 438 & $33.2(28.6-38.7)$ & $12.8(11.2-14.6)$ \\
$24-48$ & 359 & $44.2(38.4-51.1)$ & $21.9(17.2-30.0)$ \\
$48-72$ & 442 & $33.1(28.3-51.1)$ & $10.8(9.1-12.4)$ \\
$72-96$ & 400 & $43.7(37.6-50.7)$ & $21.1(17.8-24.9)$ \\
$96-120$ & 470 & $45.7(39.4-53.3)$ & $17.7(15.9-19.8)$ \\
$120-144$ & 526 & $>400$ & $71.3(58.1-87.9)$ \\
$144-168$ & 406 & $>400$ & $51.5(41.7-64.5)$ \\
\hline
\end{tabular}

of unhatched eggs; 40.6 and $85.4 \mathrm{ppm}$ based upon that of surviving larvae, respectively. The direct contact ovicidal activity of cycloprate is about two times higher than that of residual contact.

The duration of egg development of the citrus red mite was about 7.5 days under our laboratory conditions. Cycloprate was applied to eggs of different age after deposition. The hatch and survival rate of the larvae were then examined. Table 3 presents the results indicated as the $50 \%$ inhibitory concentrations for egg hatch and larval survival with 95\% confidence limits calculated by probit analysis. No significant differences in susceptibility were found in eggs during the first 120 hours after deposition. However, the susceptibility of eggs beyond 120 hours of age decreased. Although application of cycloprate to eggs 120-168 hours old at concentrations up to $400 \mathrm{ppm}$ did not inhibit emergence, the development of the hatched larvae was strongly inhibited and death resulted. This larval death may have been caused not only by some delayed ovicidal effects of cycloprate applied at the egg stage but also by larvicidal effects exerted by the residues on the leaf discs.

The developmental stage at death, following

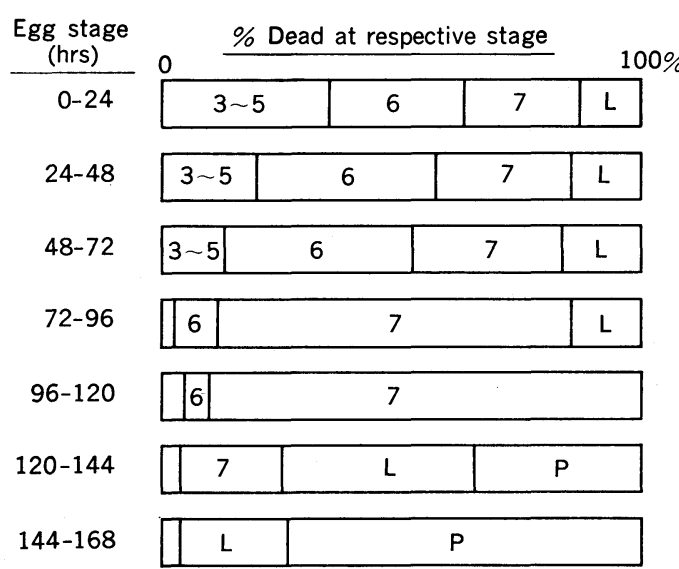

Fig. 1 Stage of development at the moment of death after treatment of eggs of different ages with cycloprate of the citrus red mite, Panonychus citri (McGregor).

3 5-post red eye spot stage, 6-blastokinesis stage, 7-pharate larval stage, L-larval stage, $\mathrm{P}$-protonymphal stage.

treatment of eggs between $0-168$ hours after deposition, was investigated and the results are shown as percentages in Fig. 1. Death in all treatments occurred beyond the red eye spot stage of development. The precise stage 
at which death occurred differed with the age of the eggs at treatment. Most of the eggs treated between 0-72 hours reached the embryonic blastokinesis stage or the pharate larval stage and then died. Some died as larvae soon after hatching without feeding. Most of the eggs aged 72-120 hours died at the pharate larval stage just before hatching with some dying as larvae soon after hatching. Almost all of the eggs 120-168 hours old hatched and subsequently died during development in the larval or protonymphal stage. Death in this group might be due to the residual larvicidal activity of cycloprate as described in the next section.

\section{Lethal Activity on Mobile Stages}

The lethal effects of cycloprate on larvae, protonymphs, deutonymphs and adults by residual contact with treated leaf discs are presented in Table 4. Usually death did not occur instantaneously but rather during further development. Therefore, in the tests with larvae or nymphs the survival was checked daily until adult ecydsis. Tests with adults were evaluated over a five day period. The mortality figures in Table 4 are based on survival at the final scoring, corrected for survival of the controls. The $50 \%$ lethal concentrations were calculated by probit analysis (Table 4). Larvae were most susceptible to cycloprate, being four and sixteen times more affected than protonymphs and deutonymphs, respectively. Adults were least susceptible and most of them survived even at the high dose level of 4,000 ppm.

However, in a separate experiment it was found that adults were killed rather quickly
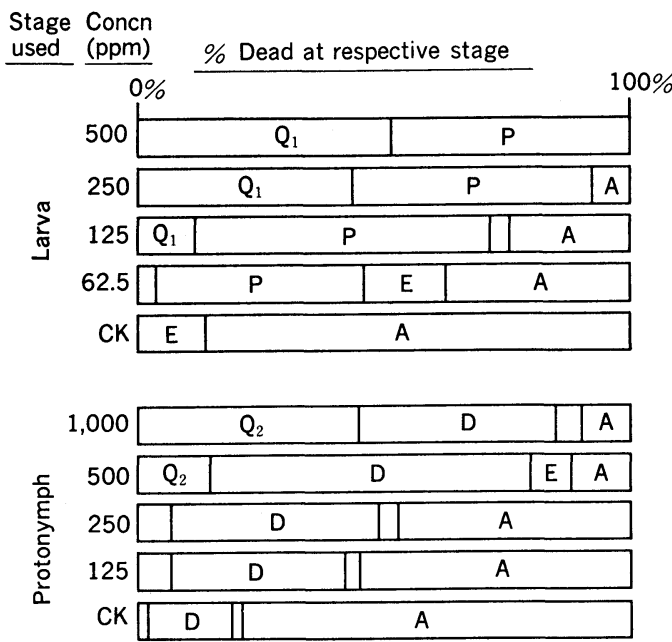

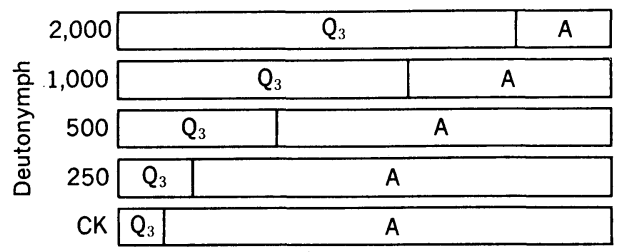

Fig. 2 Stage at death after residual treatment with cycloprate of different developmental stages of the citrus red mite, Panonychus citri (McGregor).

$\mathrm{Q}_{1}, \mathrm{Q}_{2}$. $\mathrm{Q}_{3}-1 \mathrm{st}, 2 \mathrm{nd}$, and 3rd quiescent stage, P-protonymph, D-deutonymph, A-adult (survived), E-mites escaped from the leaf discs.

Table 4 Residual insecticidal activity of cycloprate on different developmental stages of the citrus red mite, Panonychus citri (McGreqor).

\begin{tabular}{ccccc}
\hline \multirow{2}{*}{ Concn. $(\mathrm{ppm})$} & \multicolumn{5}{c}{ Mortality* $(\%)$} \\
\cline { 2 - 5 } & Larvae & Protonymphs & Deutonymphs & Adults \\
\hline 4,000 & - & - & 93.8 & 30.4 \\
2,000 & - & - & 79.2 & 24.2 \\
1,000 & - & 86.9 & 54.6 & 0.0 \\
500 & 100 & 84.9 & 24.6 & - \\
250 & 91.3 & 39.8 & 6.3 & - \\
125 & 74.0 & 31.1 & - & - \\
62.5 & 54.8 & 2.8 & - & $>4,000$ \\
LC 50 (ppm) & 60 & 248 & 1,180 & \\
\hline
\end{tabular}

* Mortality of larvae, protonymphs, and deutonymphs based on the \% survival to the adult stage. Mortality of adults based on the survival after 5 days exposure. 
with 2,000 ppm applied by direct spraying, indicating that the activity of cycloprate may differ according to the mode of application.

Observations of developmental stages at death after continuous residual contact with cycloprate on leaf discs are summarized in Fig. 2. All of the larvae exposed to the treated leaf discs at 62.5-500 ppm of cycloprate reached the first quiescent stage, but some of them succumbed during the subsequent larvalnymphal molt at the higher dose levels (250 $500 \mathrm{ppm})$. High mortality was observed in the protonymphal stage at all dose levels tested; the nymphs died soon after molting. In the tests with protonymphs all of them also reached the second quiescent stage but some of them failed during molting. High mortality in all dose levels was observed at the deutonymphal stage soon after molting. In tests with deutonymphs all developed into third quiescent stages and death by molting failure was dependent on the treatment dose level. Death in adults emerging from the third quiescent stage was insignificant. Almost all adults survived at $500 \mathrm{ppm}$.

\section{Sterilizing Activity}

Cycloprate exhibited lethal activity against both adults and nymphs as mentioned above. In direct spray tests, 2,000 ppm of cycloprate gave 89.7 and $94.6 \%$ mortality at 24 and 48 hours after treatment, respectively. Sterilization of adults surviving treatments with 500 2,000 ppm was investigated by transferring these adults to untreated leaf discs and allowing them to oviposit for 48 hours. Table 5 shows the results on egg hatch and larval survival. Adult survival for the first 24 hours after transfer was $75.0-96.7 \%$ following treatment and $95 \%$ in the controls. There was no significant difference in adult survival between treated and controls, but oviposition at the two highest dose levels of cycloprate was reduced. Egg hatch and larval survival from eggs produced during the first 24 hours after treatment were markedly suppressed. However, in the following 24 hours of oviposition by surviving adults, egg hatch and larval survival recovered considerably. These results indicate that cycloprate causes only temporary sterilization of female adults of the citus red mite.

\section{DISCUSSION}

The effectiveness of cycloprate against phytophagous mite species has been demonstrated in Tetranychus spp. ${ }^{3-5)}$ Panonychus spp., Aculus spp., Phyllocoptruta spp. and Bryobia spp. (Zoecon Corporation and Otsuka company experimental reports, unpublished). On the other hand, the compound exerts little adverse effects on predaceous mites or on beneficial insects. It also has low vertebrate toxicity. This compound, therefore, has great promise for practical mite control because of its safety and selectivity.

Cycloprate and its derivatives exhibit high ovicidal, larvicidal and sterilizing activity on phytophagous mites and they have good residual properties,, ${ }^{3,5)}$ Experimental data with Tetranychus urticae reported by Staal et al. ${ }^{3)}$ indicate that the susceptibility of 0-96 hours old eggs to cycloprate and two related compounds increased somewhat with the age of the eggs. Our studies with Panonychus citri show no significant difference in susceptibility

Table 5 Egg hatch and survival of hatched larvae in eggs laid during a $48 \mathrm{hr}$ period after dip treatment with cycloprate and subsequent transferal to untreated leaf discs by female adults of the citrus red mite Panonychus citri (McGregor).

\begin{tabular}{|c|c|c|c|c|c|c|c|}
\hline \multirow{3}{*}{$\begin{array}{l}\text { Concn. } \\
\text { (ppm) }\end{array}$} & \multirow{3}{*}{$\begin{array}{l}\text { No. of } \\
\text { adults }\end{array}$} & \multicolumn{6}{|c|}{ Hours after transferal } \\
\hline & & \multicolumn{3}{|c|}{$0-24$} & \multicolumn{3}{|c|}{$24-48$} \\
\hline & & $\begin{array}{l}\text { No. of } \\
\text { eggs }\end{array}$ & $\begin{array}{l}\% \text { Egg } \\
\text { hatch }\end{array}$ & $\begin{array}{l}\% \text { Larval } \\
\text { survival }\end{array}$ & $\begin{array}{l}\text { No. of } \\
\text { eggs }\end{array}$ & $\begin{array}{c}\% \text { Egg } \\
\text { hatch }\end{array}$ & $\begin{array}{l}\text { \% Larval } \\
\text { survival }\end{array}$ \\
\hline 2,000 & 60 & 57 & 17.5 & 0.0 & 75 & 64.0 & 44.0 \\
\hline 1,000 & 60 & 67 & 61.2 & 25.4 & 64 & 81.3 & 73.4 \\
\hline 500 & 60 & 113 & 81.4 & 51.3 & 118 & 95.8 & 94.9 \\
\hline Control & 60 & 113 & 85.0 & 85.0 & 139 & $91: 4$ & 91.4 \\
\hline
\end{tabular}


between 0-120 hour old eggs but a decrease in susceptibility in 120-168 hours eggs. However, since the larvae emerging from eggs treated at these late stages die during subsequent larval or nymphal development by a delayed lethal activity of cycloprate, it may be correct to say that the ovicidal action of cycloprate is effective against all stages of eggs of $P$. citri from a practical point of view.

To date, no knowledge has been obtained on the mode of action of cycloprate. Eggs treated with the compound generally develop as far as the pharate larval stage or, less often, to the red eye spot stage before dying. Some of the emerged larvae die without any development soon after hatching due to delayed effects of cycloprate. These facts suggest that the mechanisms of ovicidal action affect basic development process of mite embryo. A lethal activity of cycloprate against larvae, protonymphs, and deutonymphs was found. Susceptibility decreases with each further developmental stage. However, it is interesting to note that death generally occurred at a molt. That is, they all reached the following quiescent stage and then failed in the molting process. The death of nymphs soon after ecdysis from the quiescent stage is also considered to be a consequence of some failure in the molting process. This phenomenon might be similar to the death of pharate larvae and larvae soon after emergence from the eggs.

Sterilizing activity of cycloprate analogs against female mite adults has already been noted in T. urticae by Nelson \& Show. ${ }^{5}$ They obtained $83.1 \%$ nonviable eggs in the first 36 hours of oviposition after topical application while $10.2 \%$ nonviable eggs are deposited 72-144 hours post-treatment. In another test with one of the cycloprate analogs the authours show that the ration of nonviable eggs to total eggs laid during the 21 hours subsequent to exposure to treated leaves were $27.4 \%$ but the egg viability during the following 22-50 hours of oviposition returns to that of the controls. From these experimental results the conclusion is drawn that uptake of the compound by the female adults affects egg developing in the oviducts and that permanent damage to the germ tissues does not occur. The present results with $P$. citri show a very similar sterili- zation activity of cycloprate.

Biological characteristics of cycloprate having a unique chemical structure were observed in ovicidal, nymphacidal, and sterilizing activities. These events suggest that cycloprate might have a mode of action different from that of other miticides in current use. Thus it is conceivable that cycloprate will not show a significant cross resistance with current commercial miticides. Preliminary tests have already shown no cross resistance to cycloprate in a strain of Tetranychus kanzawai resistant to several miticides (Asano, unpublished).

\section{ACKNOWLEDGMENT}

The authors express their thanks to Miss Kazue Kawashimo for helpful assistance. Grateful acknowledgment is also made to Dr. G. B. Staal, Zoecon Corporation for a critical reading of the manuscript.

\section{要 約}

シクロプロパンを化学構造に持つ, 新規殺ダニ剤 cycloprate (ZARDEX®, ZR-856, hexadecyl cyclopropanecarboxylate) の生物活性がミカンハダ 二を用いて調査された．この化合物は，卵期のすべての 発育ステージに高い致死活性を示し，ほとんどの場合， 幼虫体の形成期に発育が停止した。 また, 卵処理の影響 は, ふ化後の幼虫の死亡にもみとめられた. 幼虫および 若虫にたいする致死作用は, 若龄期注ど高く, 死亡は, ほとえどが静止期あるいは静止期からの脱皮直後にみら れた。成虫にたいする致死作用は，比較的弱いが，雌成 虫の産卵括よび次世代ふ化幼虫数の減少をむたらし, 不 妊効果のあることがみとめられた。これらの生物活性か ら, cycloprate が既存の殺ダ二剂とは, その作用機構 を異にすることを示唆している。

\section{REFERENCES}

1) K. Mori: Shokubutsu-Boeki 20, 1023 (1966)

2) N. Shinkaji: Shokubutsu-Boeki 24, 455 (1970)

3) G. B. Staal, G. F. Ludvik, S. G. Nassar, C. A. Henrick \& W. E. Willy: J. Econ. Entomol. 68, 91 (1975)

4) C. A. Henrick, W. E. Willy, G. B. Staal \& C. F. Ludvik: J. Agric. Food. Chem. 24, 1023 (1976)

5) R. D. Nelson \& E. D. Show: J. Econ. Entomol. 68, 261 (1975) 